Research Article

\title{
Reduction of 4-nitrophenol Mediated by Silver Nanoparticles Synthesized using Aqueous Leaf Extract of Peronema canescens
}

\author{
Salprima Yudha $\mathbf{S}^{1, *)}$, Aswin Falahudin ${ }^{1}$, Risky Hadi Wibowo ${ }^{2}$, John Hendri³, \\ Dennie Oktrin Wicaksono ${ }^{1}$
}

\begin{abstract}
${ }^{1}$ Department of Chemistry, Faculty of Mathematics and Natural Sciences, Universitas Bengkulu Jalan W.R, Supratman, Kandang Limun, Kota Bengkulu 38122, Indonesia.

${ }^{2}$ Department of Biology, Faculty of Mathematics and Natural Sciences, Universitas Bengkulu Jalan W.R, Supratman, Kandang Limun, Kota Bengkulu 38122, Indonesia.

${ }_{3}^{3}$ Department of Chemistry, Faculty of Mathematics and Natural Sciences, Universitas Lampung Jalan Soemantri Brojonegoro No.1, Kecamatan Kedaton, Bandar Lampung, Indonesia.
\end{abstract}

Received: 21 $1^{\text {st }}$ February 2021; Revised: $19^{\text {th }}$ April 2021; Accepted: $19^{\text {th }}$ Apr 2021 Available online: 21st April 2021; Published regularly: June 2021

\section{Abstract}

In this study, we developed an alternative of 4-nitrophenol reduction mediated by silver nanoparticles (AgNPs) which was synthesized using aqueous extract of the Peronema canescens leaf through an eco-friendly approach. The reducing 4-nitrophenol to 4-aminophenol mediated by AgNPS in the presence of sodium borohydride as a hydrogen source proceeded rapidly at room temperature without any additional treatments. The AgNPS synthesis was simple and was carried out under mild conditions. Ultraviolet-visible spectroscopy was performed to examine the properties of the obtained AgNPs, which displayed an absorption peak at $431 \mathrm{~nm}$. A transmission electron microscopy analysis revealed that the AgNPs were spherical in shape and had an average particle size of $19 \mathrm{~nm}$ as determined by particle size analysis.

Copyright (C) 2021 by Authors, Published by BCREC Group. This is an open access article under the CC BY-SA License (https://creativecommons.org/licenses/by-sa/4.0).

Keywords: 4-nitrophenol; silver nanoparticles; Peronema canescens; nitro-aromatic compounds; AgNPs

How to Cite: S. Yudha S, A. Falahudin, R.H. Wibowo, J. Hendri, D.O. Wicaksono (2021). Reduction of 4nitrophenol Mediated by Silver Nanoparticles Synthesized using Aqueous Leaf Extract of Peronema canescens. Bulletin of Chemical Reaction Engineering \& Catalysis, 16(2), 253-259 (doi:10.9767/bcrec.16.2.10426.253-259)

Permalink/DOI: https://doi.org/10.9767/bcrec.16.2.10426.253-259

\section{Introduction}

Metal nanoparticles have demonstrated good catalytic activity in the UV and visible light regions, such as in the treatment of water pollutants [1]. 4-nitrophenol (4-NP) is an example of toxic and hazardous contaminant found in

* Corresponding Author.

Email: salprima@unib.ac.id; sp.yudha.s@gmail.com (S. Yudha S) industrial and agricultural raw materials [2] and is a contributor to water pollutants. Previous studies have shown that the biosynthesized AgNPs has good activity against 4-NP compounds [3], and other result shows that the catalytic efficiency of 4-NP to 4aminophenol reaches $100 \%$ [4]. In addition, the proposed method to biosynthesize AgNPs has good catalytic properties compared with methods that use $\mathrm{Au}[1], \mathrm{Pt}$ [5], and Pd [6], which are much more expensive to produce. 
Silver metal has been used for thousands of years as raw material to manufacture various objects such as jewelry, tools, and coins. With the advance of technology, the particle size of silver has reduced to the nanoscale, which provides it with unique chemical and physical properties, and the applications of silver metal has broadened due to the size reduction of silver nanoparticles (AgNPs) [7]. AgNPs have good antiyeast, $\alpha$-amylase [8], photo-catalytic [9], anticancer, antibacterial [10-12], and antiviral [13] activities. Moreover, they have applications in drug administration [14] and in sensing heavy metals, such as mercury [15], lead(II), and copper(II) ions [16].

Conventional methods for the production of silver nanoparticles use hazardous chemicals and materials in physical treatment and are considered to have a negative impact not only on the environment but also on all living organisms. Thus, a material synthesis process that has a simple methodology, low cost of production, and emphasis on eco-friendly principles can become an alternate method to synthesize silver nanoparticles. Previous studies have mentioned that the use of fruit [15], leaf, and stem extracts [13,17] of Melastoma malabathricum; root extracts of Cassia toral L [18]; microalgae [12]; Cinamon bark [11]; and biopolymer [19] have proven to be effective as a medium to produce silver nanoparticles. Other result shows that, extract of Rhus chinensis was useful in AgNPs synthesis, in the form of triangular, hexagonal, or oval. These results indicate that the bioactive compounds contained in extracts function as reducing and capping agents in the formation of AgNPs [20]. In addition, another advantage of using extracts is that during the synthesis process, the formation of AgNPs can be visually observed from the color change in the reaction solution [15].

On the other hand, Indonesia is rich in herbal plants that grow in the wild area, for example $P$. canescens which popular as Pohon Sungkai. The $P$. canescens extract has been used for a long time as an herbal medicine to treat toothache, cold, fever, and ringworm [21]. The methanol extract of $P$. canescens leaves is known to contain secondary metabolites such as alkaloids, flavonoids, terpenoids, steroids, and tannins [22]. In addition, studies have shown that the extract of young leaves of $P$. canescens has good activity as an herbal medicine and a dosage of $0.5625 \mathrm{mg} \mathrm{kg} \mathrm{w} / \mathrm{w}$ can decrease the mice body temperature by up to $29 \%[23]$.
According to a literature survey, the 4nitrophenol (4-NP) reduction mediated by silver nanoparticles (AgNPs) synthesized using the aqueous extract of the $P$. canescens leaf has not been reported to date. The present study aims to synthesize AgNPs from the extract of the $P$. canescens leaf and investigate the performance of the as-prepared AgNPs in the reduction of 4-NP to 4-aminophenol (4-AP). To the best of our knowledge, this is also the first report on the synthesis of AgNPs using the aqueous leaf extracts of $P$. canescens.

\section{Materials and Methods}

\subsection{Materials}

$P$. canescens leaves were collected from the garden of Universitas Bengkulu. Two main precursors were purchased from Merck; silver nitrate (Emsure), 4-nitrophenol. Sodium borohydride was purchased from Sigma-Aldrich $(99.99 \%)$ and was used as received.

\subsection{Instrumentations}

A UV-Vis spectrophotometer (Agilent 60) was used to monitor the reaction of the AgNP synthesis at a scanning range of $380-800 \mathrm{~nm}$ and the reduction reaction of 4-NP mediated by the as-prepared AgNPs. The size distribution of the AgNPs was determined using a particle size analyzer (PSA) (Delsa ${ }^{\mathrm{TM} N a n o}$ - Beckman Coulter Inc.). A transmission electron microscope (TEM) (JEOL JEM 1400) was utilized to investigate the shape and morphology of the AgNPs in solution.

\subsection{Experimental Procedures}

2.3.1 Synthesis of silver nanoparticles using aqueous leaves extract of $P$. canescens

The fresh leaves of $P$. canescens were washed thrice with distilled water and dried for seven days at room temperature. The dried leaf $(1 \mathrm{~g})$ was mixed with $100 \mathrm{~mL}$ distilled water and heated in a hot plate at $\pm 60{ }^{\circ} \mathrm{C}$ for 15 min under stirring. The leaf extract was filtered through filter paper (Whatman No. 1) and stored at $\pm 5{ }^{\circ} \mathrm{C}$.

An aqueous solution of silver nitrate (0.01 M) was prepared and used as starting material for the synthesis of AgNPs. In a bottle vial, about $5 \mathrm{~mL}$ of the aqueous extract of $P$. canescens was added drop wisely to $1 \mathrm{~mL}$ of the $0.01 \mathrm{M}$ silver nitrate solution. The synthesis process was conducted at room temperature under gentle stirring [15]. The solution color, during the synthesis process, immediately 
changed from yellow to dark chocolate. The formation of $\mathrm{AgNPs}$ in the solution was monitored using an ultraviolet-visible (UVVis) spectrophotometer, and the shape and size of the AgNPs was confirmed by transmission electron microscopy (TEM) and particle size analysis (PSA).

\subsubsection{Catalytic Activity Test}

The catalytic activity of the as-prepared AgNPs was evaluated using 4-NP solution (2 mM) as reaction precursor and $\mathrm{NaBH}_{4}$ solution $(0.03 \mathrm{M})$ as hydrogen source. To investigate the intermediate and other possibilities, the following solutions were prepared: Sol-A, made by mixing $1 \mathrm{~mL}$ of the 4 -NP solution and $10 \mathrm{~mL}$ aqua DM; Sol-B, consisting of $1 \mathrm{~mL}$ of the 4-NP solution, $10 \mathrm{~mL}$ aqua $\mathrm{DM}$, and $5 \mathrm{~mL}$ of $0.03 \mathrm{M}$ $\mathrm{NaBH}_{4}$ solution; and Sol-C, prepared by mixing Sol-B with $150 \mu \mathrm{L}$ of the as-prepared AgNPs. In general, all catalytic experiments were performed at room temperature under stirring [24]. The progress of the catalytic reaction was monitored at different time intervals using a $\mathrm{UV}-\mathrm{Vis}$ spectrophotometer.

\section{Results and Discussion}

Figure 1(a) shows the $P$. canescens plant, and the air-dried leaves as the main source of the extract are shown in Figure 1(b). Visual assessment of the formation of silver nanoparticles; the color of the mixture solution during the reaction changed from transparent (Figure 1(c)) to light brown (Figure 1(d)); this is an initial indication of the formation of silver nanoparticles through the reduction of $\mathrm{Ag}^{+}$ions to $\mathrm{Ag}^{0}$ [10]. The change in the color of the aqueous extract used to reduce silver ions has been previously proposed to stem from the oxidation reaction of the active compounds in the extract. This is based on the fact that the silver ion reduction process must be necessarily accompanied by the oxidation of the reducing compound or ions, constituting the so-called redox reaction [25]

The UV-Vis absorption spectrum of the leaf extract depicted in Figure 2(a) shows no peak. In contrast, the reaction mixture of the extract and silver nitrate solution showed a surface plasmon resonance band at $431 \mathrm{~nm}$ derived from the AgNPs after the reaction was kept for $48 \mathrm{~h}$ at room temperature (Figure 2(b)). This result is in line with a previous report on the use of Vigna sp. L seed extract as a reducing agent [26]. The UV-Vis spectroscopic results shown in Figure 2(b) and Figure 2(c) reveal the occurrence of surface plasmon resonance (SPR), a phenomenon specific of AgNPs [27].

The stability of AgNPs is essential for various purposes. Thus, a low stability of AgNPs results in aggregation and agglomeration, which has an impact on their characteristics, particularly their size, affording nano-sized,

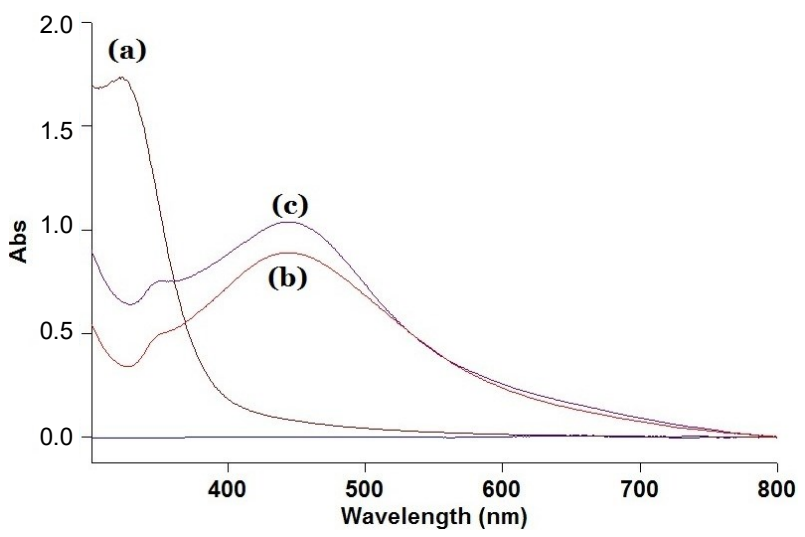

Figure 2. UV-Vis spectra of (a) aqueous extract of Peronema canescens (b) reaction mixture after $48 \mathrm{~h}$, and (c) reaction mixture after $22 \mathrm{~d}$.

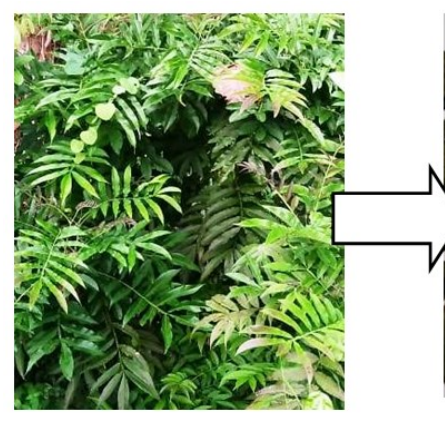

(a)

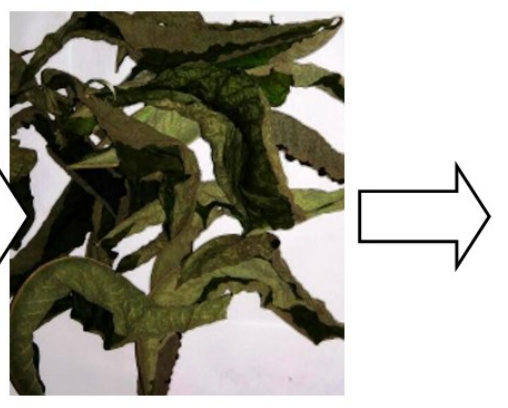

(b)

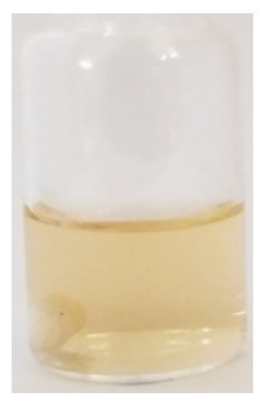

(c)

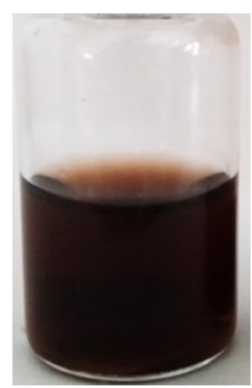

(d)

Figure 1. $P$. canescens plants: (a), $P$. canescens air-dried leaves, (b) aqueous extract of $P$. canescens airdried leaves, and $(d)$ reaction mixture of the extract and $\mathrm{AgNO}_{3}$. 
micro-sized, or bulk particles with different properties. Therefore, the investigation of the stability of AgNPs in the reaction medium is very important to ensure the practical application and cost-effectiveness of the resulting material. Interestingly, the as-prepared AgNPs solution was stable even after standing at room temperature for 22 days, which was supported by the stable UV-Vis spectrum at $431 \mathrm{~nm}$ (Figure 2c) and lack of aggregation in the bottle's bottom. The bioactive components of the $P$. canescens leaf extract are alkaloids, flavonoids, terpenoids, steroids, and tannin, which can be predicted to play important roles in the formation and stabilization of the AgNPs [14]. In addition, the stability may stem from
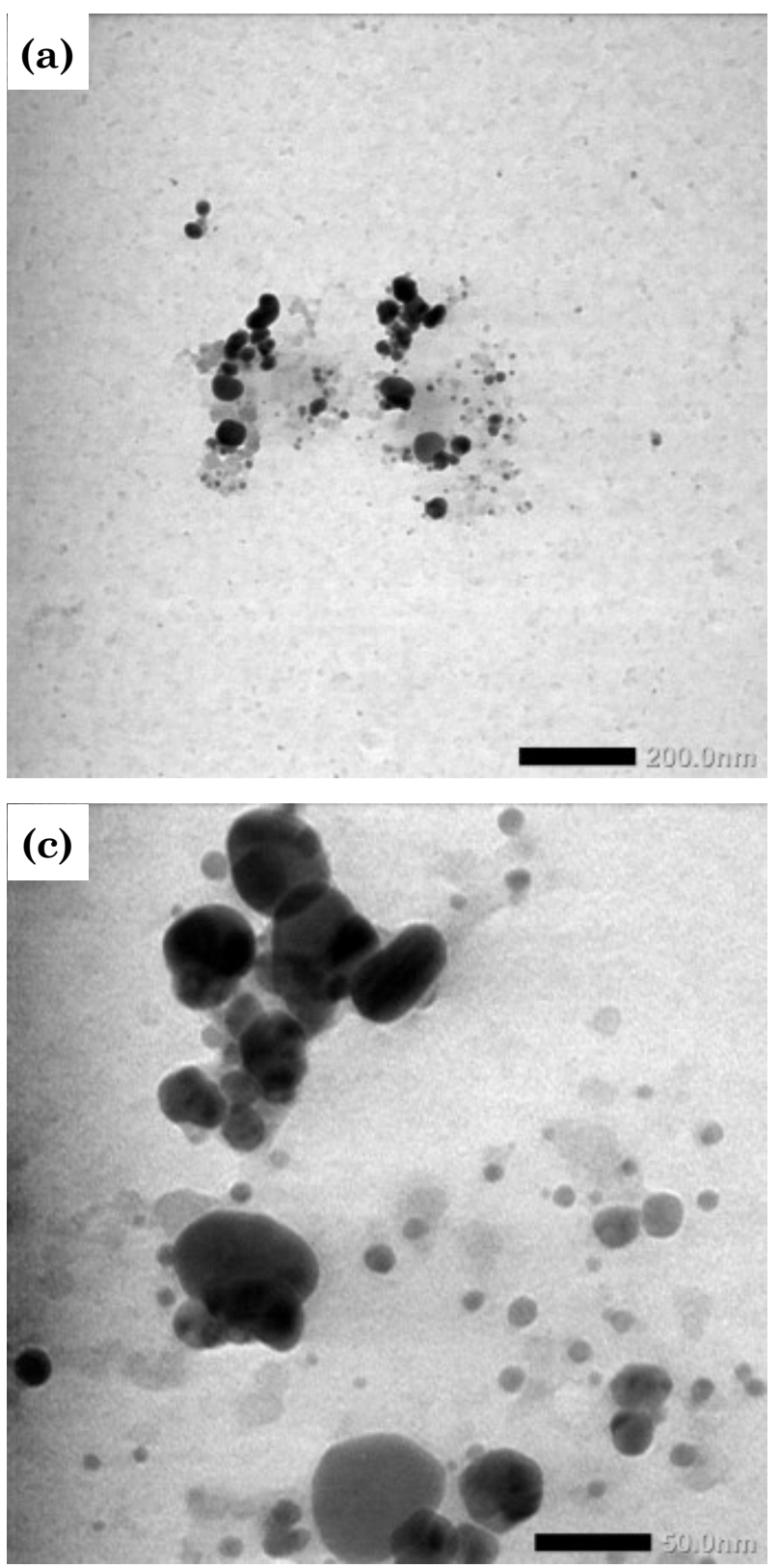

some organic compounds present in $P$. canescens leaves, such as peronemins [28].

TEM analysis confirmed that the AgNPs mainly consisted of spheres of various sizes (Figure 3). The particle size of the as-prepared $\mathrm{Ag}$ nanoparticles was analyzed by PSA and the results are presented in Figure 4. The Figure 4 shows a particle size distribution graph from which it can be inferred that the average size of the AgNPs was $19 \mathrm{~nm}$, which is similar to that obtained by TEM. Taken together, these results demonstrate the potential of $P$. canescens leaf extract as a medium for the synthesis of AgNPs and also act as a stabilizer of the silver nanoparticles.
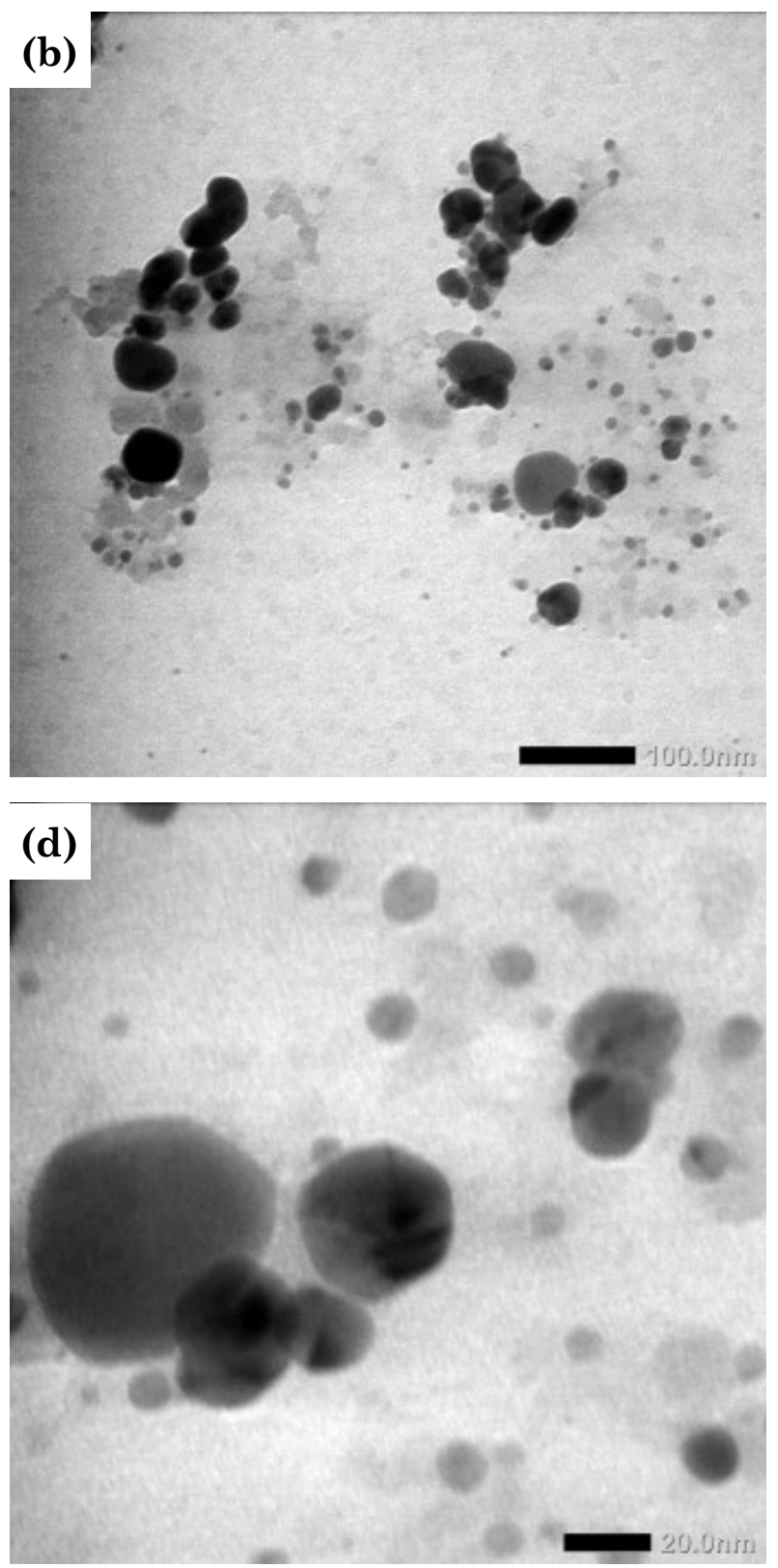

Figure 3. TEM image of as-prepared silver nanoparticles: (a) scale-bar $500 \mathrm{~nm}$, (b) scale-bar $200 \mathrm{~nm}$, (c) scale-bar $50 \mathrm{~nm}$, (d) scale-bar $20 \mathrm{~nm}$. 
In order to explore the further application of the as-prepared AgNPs, the catalytic activity of the AgNPs in the reduction of $4-\mathrm{NP}$ to 4 -AP was investigated in the presence of $\mathrm{NaBH}_{4}$ as hydrogen source. Figure 5 shows a shift in the absorption peak of the solution from $317 \mathrm{~nm}$ (Sol-A) (Figure 5(a)) to $400 \mathrm{~nm}$ (Sol-B), which is indicative of the formation of the 4-nitrophenolate intermediate [24] (Figure 5(b)) after the addition of $\mathrm{NaBH}_{4}$ into the 4-NP solution [29]. The addition of AgNPs to Sol-B causes a gradual decrease in the absorption intensity at a wavelength of $400 \mathrm{~nm}$ and an increase in the absorption intensity at $298 \mathrm{~nm}$, which is consistent with the formation of 4-AP in the catalytic process (Figure 5(c)) [30]. These results demonstrate the role of the AgNPs in the catalytic reduction of $4-\mathrm{NP}$ to $4-\mathrm{AP}$ in which the silver nanoparticles surface acts as mediator for the electron transfer from $\mathrm{BH}_{4}{ }^{-}$ donors to 4-NP acceptors in aqueous solution [31]. The 4-NP reduction process is still an active area of research. For instance, recent research results claim that the hydrogen in the metal-catalyzed 4-NP reduction comes from water rather than from $\mathrm{NaBH}_{4}$. However, $\mathrm{NaBH}_{4}$ is required as a support for water ionization to produce $\mathrm{H}^{+}$ions [32].

According to the spectrum depicted in Figure 5, the use of $150 \mu \mathrm{L}$ of an AgNPs solution (equivalent to $12.5 \mathrm{~mol} \% \mathrm{Ag}$ ) as a catalyst is sufficient to reduce $0.002 \mathrm{mmol}$ of 4 NP to 4-AP. This process is characterized by a decrease in the absorbance of the nitrophenolate ions until its complete

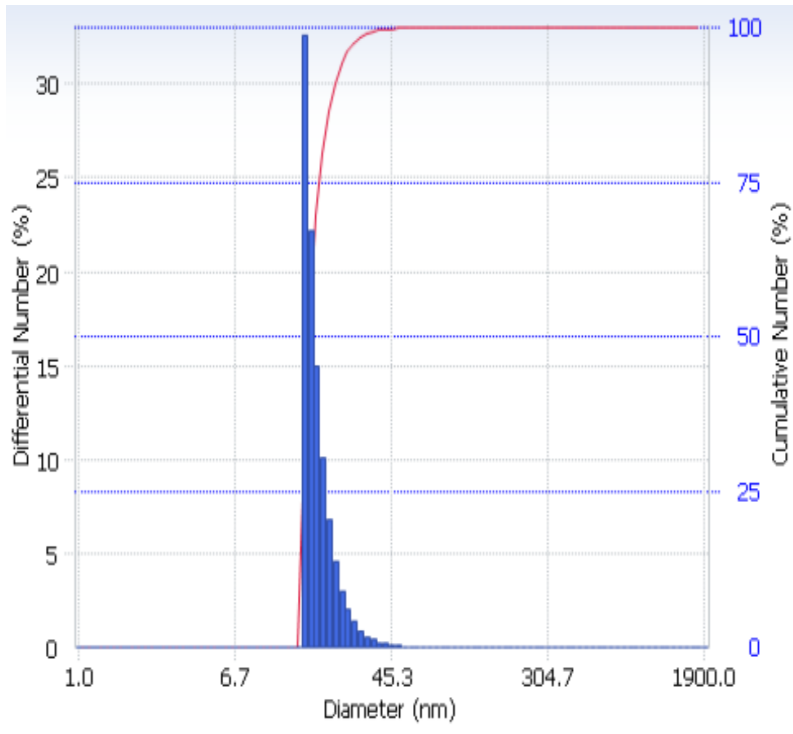

Figure 4. PSA pattern of reaction mixture between silver nitrate and aqueous extract of $P$. canescens leaf. disappearance after 30 minutes. Although the concentration of the product (4-AP) was not calculated quantitatively, the disappearance of the absorbance peak of the 4-nitrophenolate ions and the appearance of a new peak attributable to 4-AP directly indicates that a high conversion is achieved with the amount of catalyst investigated.

\section{Conclusions}

In conclusion, the reduction of 4-nitrophenol to 4-aminophenol was successfully carried out in the presence of AgNPs which was synthesized using extract of $P$. canescens leaf. The reduction reaction of 4-nitrophenol was performed without any other treatment such as heating or additional pressure. This result also show that the used silver nanoparticles was synthesized using the extract of $P$. canescens leaf for the first time in a simple and ecofriendly manner.

\section{Acknowledgment}

All authors thank Department of Chemistry, Faculty of Mathematics and Natural Sciences, Universitas Bengkulu and also Lembaga Penelitian dan Pengabdian kepada Masyarakat, Universitas Bengkulu for Percepatan Guru Besar Research grant (Contract Number 2071/UN30.15/PG/2020).

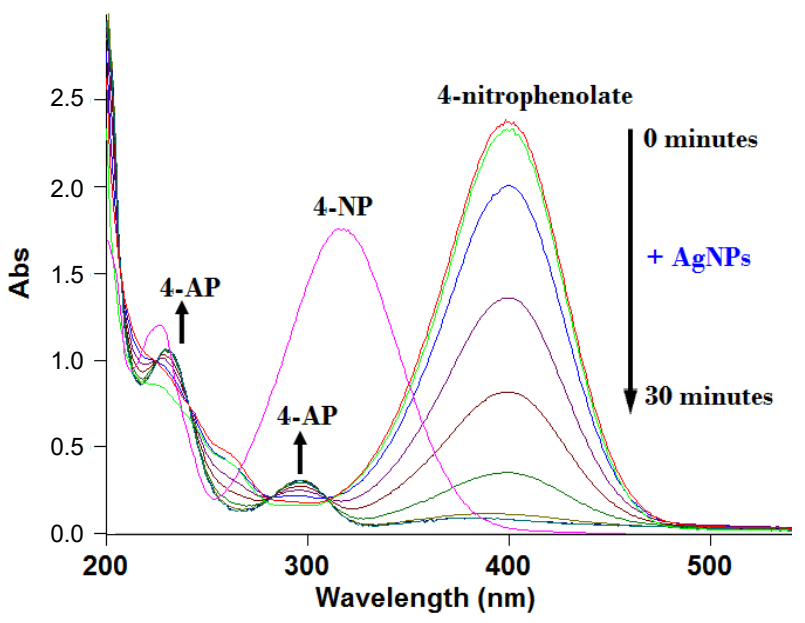

Figure 5. UV-visible spectrum of 4-nitrophenol, 4-nitrophenolate ions (4-nitrophenol in the presence of sodium borohydride), and after addition of AgNPs (0-30 min) catalyst in the reaction mixture (overlay of UV-visible spectra showing the progress of the reduction reaction at $5,10,15,20,25,30 \mathrm{~min}$. 


\section{References}

[1] Bogireddy, N.K.R,, Pal, U., Gomez, L.M., Agarwal, V. (2018). Size controlled green synthesis of gold nanoparticles using coffea arabica seed extract and their catalytic performance in 4-nitrophenol reduction. $R S C$ Advances, 8, 24819-24826. DOI: 10.1039/C8RA04332A

[2] Nandanwar, S.A, Chakraboty, M. (2012). Synthesis of colloidal $\mathrm{CuO} /-\mathrm{Al}_{2} \mathrm{O}_{3}$ by Microemulsion and its catalytic reduction of aromatic nitro compounds. Chinese Journal of Catalysis, 33, 1532-1541. DOI: 10.1016/S1872-2067(11)60433-6

[3] Aitenneite, H., Abboud, Y., Tanane, O., Solhy, A., Sebti, S., El Bouari, A. (2016). Rapid and green microwave-assisted synthesis of silver nanoparticles using aqueous Phoenix Dactylifera L. (date palm) leaf extract and their catalytic activity for 4-Nitrophenol reduction. Journal of Materials and Environmental Science, 7(7), 2335-2339. URL: https://www.jmaterenvironsci.com/Document/ vol7/vol7_N7/251-JMES-Aitenneite.pdf

[4] Singh, J., Mehta, A., Rawat, M., Basu, S. (2018). Green synthesis of silver nanoparticles using sun dried tulsi leaves and its catalytic application for 4-Nitrophenol reduction. Journal of Environmental Chemical Engineering, 6, 1468-1474. DOI: 10.1016/j.jece.2018.01.054

[5] Pandey, S., Mishra, S.B. (2014.) Catalytic reduction of p-nitrophenol stabilised by using platinum nanoparticles by guar gum. Carbohydrate Polymers, 113, 525-531. DOI: 10.1016/j.carbpol.2014.07.047

[6] Lebaschi, S., Hekmati, M., Veisi, H. (2017). Green synthesis of palladium nanoparticles mediated by black tea leaves (Camellia sinensis) extract: Catalytic activity in the reduction of 4-nitrophenol and SuzukiMiyaura coupling reaction under ligand-free conditions. Journal of Colloid and Interface Science, 485, 223-231. DOI: 10.1016/j.jcis.2016.09.027

[7] Keat, C.L., Aziz, A., Eid, A.M., Elmarzugi, N.A. (2015). Biosynthesis of nanoparticles and silver nanoparticles. Bioresources and Bioprocessing, 2, 47. DOI: 10.1186/s40643-015-00762

[8] Chouhan, S., Guleria, S. (2020). Green synthesis of AgNPs using Cannabis sativa leaf extract: Characterization, antibacterial, anti-yeast and a-amylase inhibitory activity. Materials Science for Energy Technologies, 3, 536-544. DOI: 10.1016/j.mset.2020.05.004

[9] Rani, P., Kumar, V., Singh, P.P., Matharu, A.S., Zhang, W., Kim, K.H., Singh, J., Rawat, M. (2020). Highly stable AgNPs prepared via a novel green approach for catalytic and photocatalytic removal of biological and nonbiological pollutants. Environment International, 143, 1-13. DOI: 10.1016/j.envint.2020.105924

[10] Lakshmanan, G., Sathiyaseelan, A., Kalaichelvan, P.T., Murugesan, K. (2018). Plant-mediated synthesis of silver nanoparticles using fruit extract of Cleome viscosa L.: Assessment of their antibacterial and anticancer activity. Karbala International Journal of Modern Science, 4, 61-68. DOI: 10.1016/j.kijoms.2017.10.007

[11] Premkumar, J., Sudhakar, T., Dhakal, A., Shrestha, J.B., Krishnakumar, S., Balashanmugam, P. (2018). Synthesis of silver nanoparticles (AgNPs) from cinnamon against bacterial pathogens. Biocatalysis and Agricultural Biotechnology, 15, 311-316. DOI: 10.1016/j.bcab.2018.06.005

[12] Muthusamy, G., Thangasamy, S., Raja, M., Chinnappan, S., Kandasamy, S. (2017). Biosynthesis of silver nanoparticles from Spirulina microalgae and its antibacterial activity. Environmental Science and Pollution Research, 24, 19459-19464. DOI: 10.1007/s11356-017-9772-0

[13] Sharma, V., Kaushik, S., Pandit, P., Dhull, D., Yadav, J.P., Kaushik, S. (2019). Green synthesis of silver nanoparticles from medicinal plants and evaluation of their antiviral potential against chikungunya virus. Applied Microbiology and Biotechnology, 103, 881-891. DOI: 10.1007/s00253-018-9488-1

[14] Usmani, A., Dash, P.P., Mishra, A. (2018). Metallic nanoformulations: Green synthetic approach for advanced drug delivery. Materials Science: Advanced Composite Materials, $\quad 2, \quad 1-4 . \quad$ D O I : $10.18063 / \mathrm{msacm} . \mathrm{v} 2 \mathrm{i} 1.729$

[15] Yudha S, S., Falahudin, A., Perdani, M.S., Gustian, I., Ikram, S. (2017). Melastoma malabathricum fruit extract-mediated synthesis of silver nanoparticles with sensing ability for high concentrations of mercury (II) nitrate. The Journal of Pure and Applied Chemistry Research, 6(3), 261-267. DOI: 10.21776/ub.jpacr.2017.006.03.353

[16] Cheon, J.Y., Park, W.H. (2016). Green synthesis of silver nanoparticles stabilized with mussel-inspired protein and colorimetric sensing of lead(II) and copper(II) ions. International Journal of Molecular Sciences, 17(12), 2006. DOI: 10.3390/ijms17122006

[17] Mohammadi, F., Yousefi, M., Ghahremanzadeh, R. (2019). Green synthesis, characterization and antimicrobial activity of silver nanoparticles (AgNPs) using 
leaves and stems extract of some plants. $A d$ vanced Journal of Chemistry, Section A, 2(4), 266-275. DOI: 10.33945/SAMI/AJCA.2019.4.1

[18] Shaikh, R., Syed, I.Z., Bhende, P. (2019). Green synthesis of silver nanoparticles using root extracts of Cassia toral L. and its antimicrobial activities. Asian Journal of Green Chemistry, 3, 70-81. DOI: 10.22034/ajgc.2018.132083.1073.

[19] Aadil, K.R., Pandey, N., Mussatto, S.I., Jha, H. (2019). Green synthesis of silver nanoparticles using acacia lignin, their cytotoxicity, catalytic, metal ion sensing capability and antibacterial activity. Journal of Environmental Chemical Engineering, 7, 103296. DOI: 10.1016/j.jece.2019.103296

[20] Patil, M.P., Rokade, A.A., Ngabire, D., Kim, G.D. (2016). Green synthesis of silver nanoparticles using water extract from galls of Rhus Chinensis and Its antibacterial activity. Journal of Cluster Science, 27, 1737-1750. DOI 10.1007/s10876-016-1037-4.

[21] Elsi, Y., Satriadi, T., Istikowati, W.T. (2020). Etnobotani medicines used by indigenous people of Dayak Meratus Ulang villages South Hulu Sungai District South Kalimantan. Jurnal Sylva Scienteae, 3, 193-201. URL: https://ppjp.ulm.ac.id/journals/index.php/jss/a rticle/view/1959

[22] Ibrahim, A., Kuncoro, H. (2012). Identifikasi dan aktifitas antibakteri ekstrak daun Sungkai (Peronema canescens JACK.) Terhadap beberapa bakteri patogen. Journal of Tropical Pharmacy and Chemistry, 2(1), 818. (in Indonesian language), DOI: 10.25026/jtpc.v2i1.43

[23] Yani, A.P., Putranto, A.M.H. (2014). Examination of the Sungkai young leaf extract (Peronema canescens) as an antiseptic, immunity, antiplasmodium and teratogenity in mice (Mus.muculus). International Journal of Science and Engineering, 7(1), 30-34. DOI: 10.12777/ijse.7.1.30-34

[24] Arya, G., Sharma, N., Ahmed, J., Gupta, N., Kumar, A., Chandra., R, Nimesh, S. (2017). Degradation of anthropogenic pollutant and organic dyes by biosynthesized silver nanocatalyst from Cicer arietinum leaves. Journal of Photochemistry and Photobiology B: Biology, $174, \quad 90-96$. D O I : 10.1080/21691401.2017.1354302

[25] Ahmed, R.H., Mustafa, D.E. (2020). Green synthesis of silver nanoparticles mediated by traditionally used medicinal plants in Sudan. International Nano Letters, 10, 114. DOI: 10.1007/s40089-019-00291-9
[26] Mohammadi, S., Pourseyedi, S., Amini, A. (2016). Green synthesis of silver nanoparticles with a long lasting stability using colloidal solution of cowpea seeds (Vigna sp. L). Journal of Environmental Chemical Engineering, 4(2), 2023-2032. DOI: 10.1016/j.jece.2016.03.026

[27] Jeong, S.-H., Choi, H., Kim, J.Y., Lee, T.-W. (2015). Silver-based nanoparticles for surface plasmon resonance in organic optoelectronics. Particle \& Particle Systems Characterization, 32, 164-175. DOI: 10.1002/ppsc.201400117

[28] Kitagawa, I., Simanjuntak, P., Hori, K., Nagami, N., Mahmud, T., Shibuya, H., Kobayashi, A. (1994). Indonesian medical plant. VII. Seven new clerodane-type diterpenoids, Peronemins A2, A3, B1, B2, B3, $\mathrm{C} 1$, and D1, from the leaves of Peronema canescens (Verbenaceae). Chemical and Pharmaceutical Bulletin, 42, 1050-1055. DOI: 10.1248/cpb.42.1050

[29] Otari, S.V., Patil, R.M., Nadaf, N.H., Ghosh, S.J., Pawar, S.H. (2014). Green synthesis of silver nanoparticles by microorganism using organic pollutant: its antimicrobial and catalytic application. Environmental Science and Pollution Research, 21, 1503-1513. DOI: 10.1007/s11356-013-1764-0

[30] Patil, S., Chaudhari, G., Paradeshi, J., Mahajan, R., Chaudhari, B.L. (2017). Instant green synthesis of silver-based herbo-metallic colloidal nanosuspension in Terminalia bellirica fruit aqueous extract for catalytic and antibacterial applications. 3 Biotech, 7(36), 1-12. DOI: 10.1007/s13205-016-0589-1.

[31] Khoshnamvand, M., Huo, C., Liu, J. (2019). Silver nanoparticles synthesized using Allium ampeloprasum L. leaf extract: characterization and performance in catalytic reduction of 4-nitrophenol and antioxidant activity. Journal of Molecular Structure, $1175, \quad 90-96 . \quad$ D O I : 10.1016/j.molstruc.2018.07.089

[32] Kong, X., Zhu, H., Chen, C.L., Huang, G., Chen, Q. (2017). Insights into the reduction of 4-nitrophenol to 4-aminophenol on catalysts. Chemical Physics Letters, 684, 148-152. DOI: 10.1016/j.cplett.2017.06.049 